Tajdid: Jurnal Pemikiran Keislaman dan Kemanusiaan

Vol. 3 No. 2 Oktober 2019

\title{
KARAKTERISTIK AJARAN ISLAM PERSPEKTIF UNITY AND DIVERSITY OF RELIGION
}

\author{
Nasrullah \\ Dosen STIS AL-ITTIHAD Bima \\ E_mail: nasrhul19@gmail.com
}

\begin{abstract}
Abstrak
Radikalisme dan fundamentalisme dalam memahami ajaran agama Islam semestinya dicegah dan dihentikan dalam bingkai kehidupan yang pluralitas. Tindakan pencegahan "preventive action" menjadi hal yang tepat untuk kita tinggalkan model pemahaman yang bersifat radikal dan fundamental dalam beragama dengan beralih kepada ajaran Islam yang bernilai kesatuan dalam keragaman pluralisme agama. Nilai-nilai ajaran Islam hanya bisa dicapai apabila konsep dan karakteristik ajaran Islam dikembangkan melalui pemahaman humanistik. Itulah sebabnya, karakteristik ajaran Islam memuat berbagai bidang, seperti bidang agama, muamalah (kemanusiaan) yang di dalamnya termasuk masalah pendidikan, ilmu pengetahuan, kebudayaan, sosial, ekonomi, politik, kehidupan, sosial, kesehatan, pekerjaan, serta Islam sebagai sebuah disiplin ilmu. Umat Islam harus mampu mengakomodir hal penting yang bernilai kemanusiaan dalam beberapa bidang pengetahuannya yang berlandaskan ajaran Islam.
\end{abstract}

Kata Kunci: Karakteristik, Ajaran Islam, Unity, Diversity Of Religion.

\section{Pendahuluan}

T arakteristik tiap ajaran agama-agama memiliki perbedaan masing-masing sesuai dengan pemikiran dan pemahaman terhadap al-Kitab yang dipelajari

1 sebagai dasarnya dalam beragama. Islam pun mempunyai karakteristik sendiri, berbeda dengan agama lain di dunia. Studi tentang karakteristik ajaran Islam tidaklah mudah, karena ruang lingkup permasalahan yang sangat luas. Mengenai karakteristik ajaran Islam yang berhubungan dengan bidang-bidang yang ada dalam kehidupan sehari-hari. Misalnya dalam bidang kebudayaan, pendidikan, sosial, ekonomi, politik dan sebagainya. Karakteristik tersebut dapat kita lihat dalam sumber ajaran al-Qur'an dan Hadis. Kedua sumber ini memberi karakteristik tersendiri dalam bidang-bidang tersebut yang berguna bagi kehidupan umat manusia sepanjang masa.

Ajaran Islam memiliki konsepsi yang khas dan dapat dikenali dengan berbagai bidang keilmuannya. Perbedaan karakteristik dalam Islam menunjukkan keragaman yang luas, akan tetapi umat Islam mempunyai konsepsi jiwa persatuan umat "rahmatan lil "alamin". Islam sebagai agama yang memiliki banyak dimensi, yaitu mulai dimensi keimanan, akal pikiran, ekonomi, ilmu pengetahuan dan teknologi, sampai pada kehidupan rumah tangga dan masih banyak lagi dimensi-dimensi 
lainnya. Untuk memahami berbagai dimensi ajaran Islam tersebut jelas memerlukan berbagai pendekatan yang digali dari berbagai referensi atau ilmu.

Karena pedoman dasar ajaran Islam untuk kehidupan umat Muslim adalah alQur'an dan hadis yang mana di dalamnya terdapat berbagai petunjuk tentang bagaimana seharusnya manusia itu menyikapi hidup dan kehidupan ini secara lebih bermakna dalam arti yang seluas-luasnya. Umat Muslim dituntut memiliki kecakapan dalam memahami, menghayati, dan mengamalkan nilai-nilai dalam ajaran agama Islam secara kaffah (sempurna) dalam bentuk perilakunya sebagai reprentasi dari nilai-nilai (values) keislaman seseorang dalam kehidupan bernegara dan berbangsa. Berangkat dari uraian teoritis tersebut, tulisan ini akan mendeskripsikan karakteristik ajaran Islam. Pemahaman yang secara tepat akan domain ini untuk mendukung kelangsung hidup umat Islam sehingga dapat dijadikan sebagai way of life (pandangan hidup) di tengah-tengah kesatuan (unity) dan keragaman (diversity) dalam beragama.

\section{Pengertian Karakteristik Ajaran Islam}

Istilah "karakteristik ajaran Islam" terdiri dari dua terma utama yang berbeda pengertiannya, yaitu karakteristik dan ajaran Islam. Kata 'karakteristik' dalam Kamus Besar Bahasa Indonesia (KBBI), diartikan sebagai 'sesuatu ciri khas/bentukbentuk watak/karakter yang dimiliki oleh individu, corak tingkah laku, dan tanda khusus'. Sedangkan kata 'Islam', secara etimologi dalam perspektif bahasa Arab adalah as-silm (damai), aslama (menyerahkan diri/pasrah), istislam (penyerahan secara total kepada Allah), salim (bersih dan suci), dan salam (selamat). ${ }^{1}$ Kata Islam secara terminologi diartikan sebagai pesan bahwa umat Muslim hendaknya cinta damai, pasrah kepada ketentuan Allah SWT., bersih dan suci dari perbuatan nista, serta dijamin selamat dunia dan akherat jika melaksanakan risalah Islam. Dalam ajaran Islam sendiri mengandung arti yang berbeda-beda pula. Untuk meninjau ajaran Islam dapat dikemukakan, sebagai berikut:

1. Taat dan menyerahkan diri. Orang yang memeluk Islam adalah orang yang menyerahkan diri kepada Allah SWT., dan menurut segala yang telah ditentukanNya.

2. Sejahtera, tidak tercela, tidak cacat, selamat, teteram dan bahagia. Setiap Muslim akan sejahtera, tenteram, selamat dan bahagia, baik di dunia maupun di akherat dengan tuntunan ajaran Rabbul 'alamin.

${ }^{1}$ Pengertian Islam menurut al-Qur'an, meliputi: as-silm (Q.S. al-Anfal, 8: 61); aslama (Q.S. an-Nisa', 4: 125); mustaslim (Q.S. ash-Shaffat, 37: 26); salim (Q.S. asy-Syu'ara', 26: 89); salam (Q.S. Maryam, 19: 47). A. W. Munawwir, Kamus Bahasa Arab-Indonesia Terlengkap, (Surabaya: Penerbit Pustaka Progressif, 1984). 
3. Mengaku, menyerahkan, dan menyelamatkan. Ini berarti bahwa orang yang memeluk Islam itu adalah orang yang mengaku dengan sadar adanya Allah SWT., kemudian ia menyerahkan diri pada kekuasaan-Nya dengan menurut segala titah dan firman-Nya sehingga ia selamat di dunia dan akherat.

4. Cinta damai dan sejahtera. Islam adalah agama yang membawa kepada kedamaian dan perdamaian. Orang yang memeluk Islam adalah orang yang menganut ajaran perdamaian dalam segala tingkah laku dan perbuatan.

Asy'arie, menyatakan bahwa Islam adalah penyerahan total hanya kepada Allah SWT. semata, dan karena penyertaannya yang tulus itu, maka seseorang akan mendapatkan keselamatan, kebebasan, dan kedamaian. Dalam tingkat kepasrahan total itulah, energi ilahi akan terserap ke dalam dirinya, dan ia akan mendapat kebebasan, keselamatan, dan kedamaian yang sesungguhnya. Kepasrahan yang tulus kepada Allah SWT. adalah sumber energi dan kekuatan kreatif yang tidak pernah kering untuk mendorong kebajikan dan kesalihan. ${ }^{2}$ Agama Islam mengajarkan berbagai pedoman hidup dari akidah, ibadah, sosial, dan politik. Secara global, alQur'an mengarahkan manusia pada berbagai aspek kehidupan, sebagai berikut:

1. Prinsip ideologi Islam (Q.S. al-An'am [6]: 162-164);

2. Aturan moralitas dan tingkah laku dalam Islam (Q.S. al-Isra' [17]: 23-37);

3. Pedoman mengarahkan perasaan dalam Islam (Q.S. al-Hadid [57]: 22-23 dan anNisaa' [4]: 104);

4. Sistem sosial kemasyarakatan (Q.S. Ali-Imran [3]: 64 dan al-`Alaq [96]: 1-5);

5. Sistem politik kenegaraan (Q.S. an-Nisa' [4]: 59);

6. Sistem perekonomian Islam (Q.S. al-Baqarah [2]: 3, at-Taubah [9]: 60, dan alHasyr [59]: 7);

7. Sistem hukum dan perundang-undangan (Q.S. al-Maidah [5]: 50), dan;

8. Sistem Kemiliteran Islam (Q.S. al-Anfal [8]: 39 dan 60-61). ${ }^{3}$

Berangkat dari beberapa pengertian tersebut di atas, karakteristik ajaran Islam adalah suatu watak/karakter yang dimiliki oleh setiap umat Muslim dengan berpedoman pada al-Qur'an dan al-Hadist dalam berbagai ilmu pengetahuan dan kehidupan manusia dalam bidang agama, muamalah (kemanusian), ekonomi, sosial, politik, pendidikan, kesehatan, pekerjaan, lingkungan hidup, dan disiplin ilmu. Dengan banyaknya bidang-bidang keilmuan tersebut diperlukan kepada umat Muslim untuk memahami secara mendalam ajaran Islam yang senantiasa membawa umat manusia dalam kehidupan yang cinta damai dan sejahtera.

\footnotetext{
57.

${ }^{2}$ Musa Asy'arie, Dialektika Agama untuk Pembebasan Spiritual, (Yogkarta: LESFI, 2002),

${ }^{3}$ Ajat Sudrajat, dkk., Pendidikan Agama Islam, (Yogyakarta: UNY Press, 2008), 41.
} 


\section{Memahami dan Mengamalkan Ajaran Islam}

Selama ini kita sudah mengenal Islam, tetapi Islam dalam potret yang bagaimanakah yang kita kenal itu, tampaknya masih merupakan suatu persoalan yang perlu didiskusikan lebih lanjut. Misalnya mengenal Islam dalam potret yang ditampilkan Iqbal dengan nuansa filosofis dan sufistiknya, Islam yang ditampilkan Fazlur Rahman bernuansa historis dan filosofis. Demikian juga, Islam yang ditampilkan pemikir-pemikir dari Irak seperti Ali Syari'ati, Sayyed Husein Nasr, dan Murthada Muthahhari. Para pemikir Islam dari Iran ini terkesan banyak menguasai pemikiran filsafat modern serta ilmu-ilmu sosial yang berasal dari Barat. Mereka telah menunjukkan sisi kelemahan dari berbagai pemikiran filsafat modern dan ilmu sosial dari Barat, melalui kritiknya yang akurat serta solusi yang ditawarkannya dari Islam yang dibangun dari pendekatan filosofis sufistik. Di Indonesia kita mengenal pemikiran Islam dari Harun Nasution yang banyak menggunakan pendekatan filosofis dan historis sebagai acuannya. Muncul pula M. Rasyidi melalui pendekatan normatif legalistik yang melihat bahwa potret Islam yang ditampilkan Nasution di nilai kurang menunjukkan Islam sebagai yang dikehendaki al-Qur'an dan al-Hadist. ${ }^{4}$

Pendapat di atas, bukan hanya lebarnya jurang perbedaan pendapat antara para pemikir Islam, akan tetapi merupakan suatu rangkaian pemikiran para tokoh yang mengkaji Islam dengan menggunakan pendekatannya masing-masing sesuai dengan disiplin ilmu. Mengenai perbedaan pendapat di kalangan umat Muslim sudah menjadi "sunatullah". Dalam hadis Nabi Muhammad SAW. yang menyataka bahwa "Ikhtilaf ummati rahmah" (perbedaan umatku adalah rahmat). Hadis ini seringkali menjadi pembenaran adanya konflik dan pemecahan, padahal dalam kenyataan konflik dan pemecahan cenderung menjadi azab, menyengsarakan dan menggelisahan bukan menjadi rahmat, tidak membahagiakan, dan tidak menenangkan hati. Pertentangan yang dimaksud oleh hadis ini seharusnya diartikan sebagai perlunya penghargaan atas adanya pluralitas pendapat, budaya, dan aliran keagamaan, dengan mendapatkannya bukan sebagai tujuan dan sesuatu yang absolut, tetapi sebagai alat dan sesuatu yang bersifat relatif. Adanya perbedaan ini tidak boleh menimbulkan perbuatan dan tindakan yang merugikan sesama umat karena ada hadis yang menegaskan bahwa seorang Muslim adalah orang yang lidah dan tangannya dapat menyelamatkan orang lain, artinya "Tidak menyakiti dan menyakitkan" (al-Muslim man salimal Muslimun min lisanih wa yadih). Padahal untuk menjawab atau menyikapi permasalahan ini, alQur'an dan al-Hadist memberikan metode yang tepat dan benar dalam memahami dan mengamalkan ajaran Islam. Sebagaimana firman Allah SWT.: "Maka apakah

\footnotetext{
${ }^{4}$ Abudin Nata, Metodologi Studi Islam, (Jakarta: RajaGrafindo Persada, 2011), 77-78.
} 
mereka tidak memperhatikan al-Qur'an? Kalau kiranya al-Qur'an itu bukan dari sisi Allah, tentulah mereka mendapat pertentangan yang banyak di dalamnya".

Dalam surat lain, Allah SWT. Berfiman: "Hai manusia, sesungguhnya Kami menciptakan kaти dari seorang laki-laki dan seorang perempuan dan menjadikan kamu berbangsa-bangsa dan bersuku-suku supaya kamu saling kenal-mengenal. Sesungguhnya orang yang paling mulia di antara kamu di sisi Allah ialah orang yang paling taqwa di antara kamu. Sesungguhnya Allah Maha Mengetahui lagi Maha Mengenal". ${ }^{6}$ Sebagai hamba yang beriman, diperintah untuk bisa menerima bahwa adanya berbagai macam perbedaan pendapat dan paham itu sudah merupakan ketetapan Allah SWT., dan sudah seharusnya kaum Muslim menyikapi dengan wajar. Dalam arti tetap menjalin interaksi dan toleransi terhadap berbagai macam aliran dan golongan dengan tetap mempertahankan nilai-nilai Islam. Untuk itulah, misi Islam sebagai menebarkan ajaran keselamatan, baik dunia maupun akherat. Umat Muslim seharusnya secara keseluruhan mengaktualisasikan nilai-nilai yang terkandung di dalam ajaran Islam sebagai rujukan hidup dan kehidupan di era kontemporer. Karena itu, misi Islam sebagai pembawa rahmat dapat dilihat dari pengertian Islam itu sendiri dan pembawa rahmat dapat dilihat dari peran yang diaktualisasikan umat Islam dalam menangani berbagai problematika agama, sosial, ekonomi, politik, dan sebagainya.

\section{Konsep dan Karakteristik Ajaran Islam}

Dari berbagai sumber tentang Islam yang ditulis para tokoh, dapat diketahui bahwa Islam memiliki karakteristik yang khas yang dapat dikenali melalui konsepsinya dalam berbagai bidang, seperti bidang agama, mu'amalah (kemanusiaan) yang di dalamnya termasuk masalah pendidikan, ilmu pengetahuan, kebudayaan, sosial, ekonomi, politik, kehidupan, lingkungan hidup, kesehatan pekerjaan, serta Islam sebagai sebuah disiplin ilmu. Konsep ajaran Islam dalam berbagai bidang yang menjadi karakteristik ajaran Islam itu dapat dikemukakan, ${ }^{7}$ sebagai berikut:

\section{Bidang Agama}

Karakteristik ajaran Islam dalam bidang agama adalah mengakui adanya pluralisme sebagai sesuatu kenyataan, mengakui adanya universalisme, yakni mengajarkan kepercayaan kepada Tuhan dan hari akhir, menyuruh berbuat baik, dan mengajak pada keselamatan. Islam adalah agama yang kitab sucinya dengan tegas mengakui hak agama lain, kecuali yang berdasarkan paganisme, dan menjalankan ajaran masing-masing dengan penuh kesungguhan. Al-Qur'an menjelaskan tentang

\footnotetext{
${ }^{5}$ Q.S. an-Nisa', 4: 82.

${ }^{6}$ Q.S. al-Hujurat, 49: 13.

${ }^{7}$ Nata, Metodologi ..., 79-94.
} 
pengakuan akan hak agama-agama lain yang merupakan dasar paham kemajemukan sosial budaya dan agama sebagai ketetapan Tuhan yang tidak berubah-ubah. ${ }^{8}$ Dengan demikian, karakteristik ajaran Islam dalam visi keagamaannya bersifat toleransi, pemaaf, tidak memaksa, dan saling menghargai karena dalam pluralitas agama tersebut terdapat unsur kesamaan, yaitu pengabdian kepada Tuhan.

\section{Bidang Ibadah}

Secara harfiah karakteristik ajaran Islam dalam bidang ibadah berarti bakti manusia kepada Allah SWT., karena didorong dan dibangkitkan oleh akidah tauhid. Sebagaimana Allah SWT. Firman: "Dan aku tidak menciptakan jin dan manusia melainkan supaya mereka mengabdi kepada-Ku. Aku tidak menghendaki rejeki sedikit pun dari mereka dan Aku tidak menghendaki supaya mereka memberi-Ku makan. Sesungguhnya Allah, Dialah Maha Pemberi rejeki yang mempunyai Kekuatan lagi sangat kokoh". . Adapun ibadah dalam arti umum, bersentuhan dengan masalah mu'amalah sesuai dengan visi Islam tentang ibadah adalah merupakan sifat, jiwa, dan misi ajaran Islam itu sendiri yang sejalan dengan tugas penciptaan manusia, sebagai makhluk yang hanya diperintahkan agara beribahah kepada-Nya.

\section{Bidang Akidah}

Akidah dalam Islam meliputi keyakinan dalam hati tentang Allah sebagai Tuhan yang wajib disembah; ucapan dengan lisan dalam bentuk dua kalimat syahadat, yaitu menyatakan tidak ada Tuhan selain Allah, dan bahwa Nabi Muhammad sebagai utusan-Nya; perbuatan dengan amal saleh. Artinya, orang yang beriman tidak ada rasa dalam hati, atau ucapan di mulut dan perbuatan melainkan secara keseluruhan menggambarkan iman kepada Allah, yakni tidak ada niat, ucapan, dan perbuatan yang dikemukakan oleh orang yang beriman itu kecuali yang sejalan dengan kehendak Allah. Akidah dalam Islam selanjutnya harus berpengaruh ke dalam segala aktivitas yang dilakukan manusia, sehingga berbagai aktivitas tersebut bernilai ibadah dan dasar dalam tingkah laku, serta berbuat yang pada akhirnya menimbulkan amal saleh.

\footnotetext{
${ }^{8}$ Kemajemukan agama yang dijelaskan di dalam al-Qur'an (Q.S. al-Ma'idah, 5: 44-50); beriman kepada semua nabi dan rasul tanpa membeda-bedakan antara mereka, baik dalam kitab suci maupun yang tidak disebutkan (Q.S. al-Baqarah, 2: 136 dan an-Nisa', 4: 163-165); agama tidak boleh dipaksakan (Q.S. al-Baqarah, 2: 256); al-Qur'an mengisyaratkan bahwa para penganut berbagai agama, asalkan percaya kepada Tuhan dan hari akhir, serta berbuat baik semuanya akan selamat (Q.S. al-Baqarah, 2: 62 dan al-Ma'idah, 5: 26).

${ }^{9}$ Q.S. adz-Dzariyat, 51: 56-58.
} 


\section{Bidang Ilmu dan Kebudayaan}

Karakteristik ajaran Islam dalam ilmu dan kebudayaan bersikap terbuka, akomodatif, tetapi juga selektif. Dari satu segi Islam terbuka dan akomodatif untuk menerima berbagai masukan dari luar, tetapi bersamaan dengan itu Islam juga selektif, yakni tidak bergitu saja menerima seluruh jenis ilmu dan kebudayaan, melainkan ilmu dan kebudayaan yang sejalan dengan ajaran Islam sendiri. Dalam konteks historis Islam di bidang ilmu dan kebudayaan menjadi mata rantai yang penting dalam peradaban dunia. Persoalan kebudayaan adalah persoalan bagaimana manusia mewujudkan eksistensi dirinya dengan kekuatan akal, hati, dan jiwa dalam lapangan hidup dan cara-cara yang ditempuhnya dalam menghadapi tantangan kesejarahan. Lapangan kebudayaan begitu luas, seluas lapangan kehidupan manusia di antaranya adalah keyakinan (agama), ilmu pengetahuan, bahasa, adat-istiadat, pranata sosial, institusi sosial, hukum, seni, budaya, dan sebagainya. ${ }^{10}$ Demikian pentingnya ilmu ini hingga Islam memandang bahwa orang menuntut ilmu sama nilainya dengan jihad di jalan Allah.

\section{Bidang Pendidikan}

Senada dengan bidang ilmu pentahuan dan kebudayaan di atas, Islam juga memiliki ajaran yang khas di bidang pendidikan. Dalam sejarah kebudayaan Islam, akulturasi operasional pendidikan Islam yang berpedoman pada al-Qur'an dan alHadist secara serasi dan seimbang, telah mampu memberikan motivasi dan inspirasi umat Islam pada masa klasik dalam merumuskan berbagai persepsi mengenai manusia melalui pendidikan sebagai sarana yang mendasari lahirnya peradaban dunia. ${ }^{11}$ Islam memandang pendidikan adalah hak bagi tetiap orang (education for all), laki-laki atau perempuan, dan berlangsung sepanjang hayat (long life education). Dalam bidang pendidikan, Islam memiliki rumusan yang jelas dalam bidang tujuan, kurikulum, guru, metode, sarana, dan lain sebagainya. Di dalam al-Qur'an terdapat berbagai metode pendidikan, seperti metode caramah, tanya-jawab, diskusi, demonstrasi, penugasan, teladan, pembiasaan, hukuman, nasihat, dan lain-lain.

\section{Bidang Sosial}

Karakteristik ajaran Islam di bidang sosial, bahwa Islam mengajarkan setiap manusia untuk hidup damai dan sejahtera. Lebih khususnya, di bidang ini Islam menjunjung tinggi tolong-menolong, saling menghargai tentang hak dan kewajiban, kesetiakawaan, egaliter (kesamaan derajat), tenggang rasa, dan kebersamaan. Atas

\footnotetext{
${ }^{10}$ Syamsul Bakri, Peta Sejarah Peradaban Islam, (Yogyakarta: Fajar Media Press, 2011), 2-3.

${ }^{11}$ Susanto, Pemikiran Pendidikan Islam, (Jakarta: Amzah, 2010), 2.
} 
dasar ukuran ini, maka dalam Islam semua orang memiliki kesempatan yang sama. Mobilitas vertikal dalam arti yang sesungguhnya ada dalam Islam, sementara sistem kelas yang menghambat mobilitas sosial tersebut tidak diakui keberadaannya. Dalam hal ini, Bryan S. Turner memahami fungsi sosial bagi masyarakat manusia, para sosiolog agama menempatkan agama sebagai perekat sosial yang merekat potensipotensi antagonistik antar-individu atau sebagai candu sosial yang menekan konflik kepentingan antara kelompok-kelompok yang cenderung antagonistik. ${ }^{12}$ Kendati demikian, Islam menilai bila urusan ibadah dilakukan tidak sempurna atau batal, karena melanggar pantangan tertentu, maka kifarat (tembusannya) adalah dengan melakukan sesuatu yang berhubungan dengan urusan sosial.

\section{Bidang Kehidupan Ekonomi}

Islam memandang bahwa kehidupan yang harus dilakukan manusia adalah hidup yang seimbang dan tidak terpisahkan antara urusan dunia dan akherat. Padangan Islam mengenai kehidupan demikian, secara tidak langsung menolak kehidupan yang bercorak sekularistik, yaitu kehidupan yang memisahkan antara urusan dunia dengan urusan agama. Agama harus terlihat dalam mengatur kehidupan dunia. Sistem ekonomi dalam Islam mempunyai beberapa kelebihan yang tercermin dari beberapa karakteristik, meliputi: pertama, bersumber dari Tuhan dan Agama. Sumber awal ekonomi Islam berbeda dengan sistem ekonomi lainnya karena merupakan kewajiban dari Allah. Ekonomi Islam dari agama Allah dan mengikat semua manusia tanpa terkecuali. Sistem ini meliputi semua aspek universal dan partikular dari kehidupan dalam satu bentuk, sebagai pondasi dan ekonomi Islam tidak bisa berubah.

Kedua, ekonomi pertengahan dan berimbang. Ekonomi Islam memadukan kepentingan pribadi dan kemaslahatan masyarakat dalam bentuk berimbang. Ekonomi Islam berposisi tengah antara aliran individualis (kapitalis) yang melihat bahwa hak kepemilikan individu bersifat absolut dan tidak boleh diintervensi oleh siapapun dan aliran sosialis (komunis) yang menyatakan ketiadaan hak individu dan mengubahnya kedalam kepemilikan bersama dengan menempatkannya di bawah dominasi negara. Ketiga, ekonomi berkecukupan dan berkeadilan. Ekonomi Islam memiliki keunggulan dengan menjadikan manusia sebagai fokus perhatian. Manusia diposisikan sebagai pengganti Allah di bumi untuk memakmurkannya dan tidak hanya untuk mengeksploitasi kekayaan dan memanfaatkannya saja. Ekonomi ini

\footnotetext{
${ }^{12}$ Bryan S. Turner, Religion and Social Theory, terj. Inyiak Ridwan Munir, (Yogyakarta: IRCiSoD, 2012), 212.
} 
ditujukan untuk memenuhi dan mencukupi kebutuhan manusia, hal ini berbeda dengan ekonomi kapitalis dan sosialis di mana fokus pertanian adalah kekayaan.

Keempat, ekonomi pertumbuhan dan barakah. Ekonomi Islam memiliki kelebihan lain, yaitu beroperasi atas dasar pertumbuhan dan investasi harta dengan cara legal, agar dari mediasi jaminan kebutuhan-kebutuhan pokok bagi manusia. Islam memandang harta dapat berkembang hanya bekerja. Hal itu hanya dapat terwujud dalam usaha kerja keras untuk menumbuhkan dan memperluas unsur-unsur produksi demi terciptanya hasil yang lebih baik. Usaha itu dilakukan melalui perputaran modal di tengah masyarakat Islam dalam bentuk modal produksi sebagai kontribusi dalam aturan-aturan yang berkembang. ${ }^{13}$

\section{Bidang Kesehatan}

Ciri khas ajaran Islam selanjutnya dapat dilihat dalam konsepnya mengenai kesehatan. Untuk menuju hal tersebut, Islam menekankan segi kebersihan lahir dan batin. Sementara itu Islam memandang kebersihan lahir-batin (jiwa) dalam istilah nafs, akhlak, dan irfan. ${ }^{14}$ Artinya, kebersihan jiwa manusia dapat mengambil bentuk kebersihan tempat tinggal, lingkungan sekitar, badan, pakain, makanan, minuman, dan lain-lain, firman Allah SWT.: "Sesungguhnya Allah menyukai orang-orang yang bertaubat dan senang kepada orang-orang yang membersihkan diri". ${ }^{15}$ Sedangkan pada kebersihan batin dapat diwujudkan melalui bentuk keikhlasan dan kekhusukan, ${ }^{16}$ perintah tersebut berbarengan dengan perintah menyampaikan ajaran Islam dan membesarkan nama Allah SWT.

\section{Bidang Politik}

Sejarah politik dunia Islam dapat dilihat pada tiga periode; pertama, periode klasik (650-1250 M); kedua, periode pertengahan (1250-1800 M); dan, ketiga, periode modern (1800 sampai sekarang). Pada periode pertama inilah terjadi apa yang disebutkan dengan "masa keemasan" dalam sejarah Islam. Karena itu, uraian sejarah

${ }^{13}$ Abdullah Abdul Husain at-Tariqi, Ekonomi Islam: Prinsip, Dasar, dan Tujuan, terj. M. Irfan Syofwani, (Yogyakarta: Magistra Insania Press, 2004), 15-19.

${ }^{14} \mathrm{Nafs}$ dapat diartikan dengan jiwa, ruh, semangat, dan hasrat, lebih lanjutnya mengenai jiwa diartikan dengan: (1) ruh manusia [yang ada di dalam tubuh dan menghidupkan] atau nyawa; (2) seluruh kehidupan batin manusia [yang terjadi dari perasaan, pikiran, angan-angan, dan sebagainya]. Akhlak dapat diartikan sebagai watak, tabi'at, perilaku, dan tindakan manusia dalam segala bentuk kegiatannya dalam kehidupan sehari-hari. 'irfan dapat diartikan dengan ma'rifat (pengetahuan), yang kemudian 'irfan lebih dikenal sebagai terminologi tasawuf yang berkaiatan pengetahuan esoterik, atau yang terkenal dengan istilah gnostik.

${ }^{15}$ Q.S. al-Baqarah [2]: 222.

${ }^{16}$ Firman Allah SWT: "Sesungguhnya beruntunglah orang-orang yang beriman, (yaitu) orang-orang yang khusyu' dalam sembahyangnya" (Q.S. Al-Mukminun [23]: 1-2). 
politik Islam sangat dominan, sementara aspek-aspek lain tampak hanya terikut di dalamnya seperti sistem pemerintahan, ekonomi, ilmu pengetahuan, pendidikan, dan seni bangunan. ${ }^{17}$ Islam tidak menetapkan bentuk pemerintahan tertentu, oleh karena setiap bangsa boleh saja menentukan bentuk negaranya masing-masing sesuai seleranya. Namun, yang terpenting bentuk pemerintahan tersebut harus digunakan sebagai alat untuk menegakkan keadilan, kemakmuran, kesejahteraan, keamanan, kedamaian, dan ketenteraman masyarakat. Di era kontemporer ini masalah politik, berhubungan dengan bentuk pemerintahan. Hal ini sebagaimana kita mengenal berbagai bentuk pemerintah seperti republik yang dipimpin presiden, kerajaan yang dipimpin raja, dan sebagainya.

\section{Bidang Pekerjaan}

Karakteristik ajaran Islam lebih lanjut dapat dilihat dari ajarannya mengenai kerja. Islam memandang bahwa kerja sebagai ibadah kepada Allah SWT. Atas dasar ini, maka kerja yang dikehendaki Islam adalah kerja yang bermutu, terarah pada pengabdian terhadap Allah SWT., dan kerja yang bermanfaat bagi orang lain. Allah berfirman: "Dialah yang menjadikan mati dan hidup, supaya dia menguji kamu, siapa di antara kamu yang lebih baik amalnya. Dan dia Maha Perkasa lagi Maha Pengampun". ${ }^{18}$ Untuk menghasilkan produk pekerjaan yang bermutu, Islam memandang kerja yang dilakukan adalah kerja profesional, yaitu kerja yang didukung ilmu pengetahuan, keahlian, pengalaman, kesungguhan, dan seterusnya.

\section{Bidang Disiplin Ilmu}

Selain sebagai ajaran yang berkenaan dengan berbagai bidang kehidupan dengan ciri-cirinya yang khas tersebut, Islam juga telah tampil sebagai sebuah disiplin ilmu, yaitu ilmu keislaman. Karakteristik ajaran Islam di bidang disiplin ilmu ini, Islam memandang berbagai disiplin ilmu seperti ilmu al-Qur'an (tafsir), hadis (ilmu hadis), ilmu kalam, filsafat, tasawuf, hukum Islam (fiqh), sejarah dan kbudayaan Islam, serta pendidikan Islam. Mengenai karakteristik ajaran Islam yang secara dominan ditandai oleh pendekatan normatif, historis, dan filosofis tersebut terlihat bahwa Islam memiliki ciri-ciri yang secara keseluruhan amat ideal. Oleh karena itu, Islam agama yang mengajarkan kedamaian, toleransi, terbuka, kebersamaan, egaliter, kerja keras yang bermutu, demokratis, adil, seimbang antara urusan dunia dan akherat, berharta, memiliki kepekaan terhadap masalah-masalah sosial kemasyarakatan, mengutamakan pencegahan daripada penyembuhan dalam bidang kesehatan dengan cara memperhatikan segi kebersihan badan, pakain,

\footnotetext{
${ }^{17}$ Badri Yatim, Sejarah Peadaban Islam, (Jakarta: Rajawali Pers, 2010), 5-6.

${ }^{18}$ Q.S. al-Mulk, 67: 2.
} 
makanan, tempat tinggal, lingkungan, dan sebagainya. Islam juga menampilkan sebuah disiplin ilmu keislaman dengan berbagai cabang studinya masing-masing.

\section{Ajaran Islam: Perspektif Unity dan Diversity of Religion}

Representasi dari konsep dan karakteristik ajaran Islam di atas, Islam merujuk pada peradaban dan berorientasi dunia. Islam tidak hanya sebuah agama yang menurut makna modern yang terbatas. Karena pandangan orang Islam tentang dunia selalu terpadu dan menyeluruh, dengan komitmen beragama yang dipandang sebagai inti darimana semua hal lain berasal, hampir tidak mungkin membuat garis (pemisah) antara sisi pengalaman Islam yang agamis (religious) dengan sisi yang tidak agamis. Para pakar Islam menganggap perbedaan semacam itu tidak benar, mengamati budaya tradisional dunia Islam yang semakin kuat penolakannya terhadap perbedaan tersebut. Meskipun dalam beberapa tahun terakhir sekularisme dan pandangan sekuler merasuki pemikiran Islam, namun sebagian besar umat Islam tidak mudah menerimanya. Pemikir-pemikir Islam mengadopsi sejumlah cara untuk menghindari implikasi radikal sekularisme. Untuk itu, diperlukan adanya upaya sungguh-sungguh untuk merubah aspek-aspek kehidupan sosial, meskipun akan menimbulkan transformasi besar dalam masyarakat Islam tradisional. Masalah yang dihadapi dalam upaya memahami konsep Islam disebabkan luasnya konsep, fakta yang ada, dan keragaman tingkat pemahaman di antara umat Islam sendiri. ${ }^{19}$ Max Weber, menyatakan keberadaan agama di ruang sosial dalam bukunya "The Sociology of Religion" bahwa bagi Islam, konsep organik dengan seluruh kompleks masalahnya ini agak jauh dari perhatian karena penolakannya terhadap universalisme, membuat stratifikasi sosial idealnya terdiri atas orang beriman dan tidak di mana yang pertama mendominasi yang kedua. ${ }^{20}$

Dari aspek-aspek yang kompleks pada kubu Islam, munculnya pemikiran yang berbeda dalam mengkaji aspek, seperti aspek keagamaan, historis, filosofis dan sosiologis, sehingga Islam memiliki karakteristik ajaran Islam dalam bidang agama, budaya dan peradaban. Akumulasi dari berbagai budaya yang diilhami spirit alQur'an dan al-Hadist ini menjadi peradaban Islam yang besar menjadi peradaban besar masyarakat dunia. Dari semuanya hal tersebut merupakan simbolitas dari budaya yang dimiliki oleh umat Islam, maka dengan berberapa aspek tadi mendeskripsikan bahwa Islam sebagai inspirasi dari peradabannya. Islam mengajarkan bagi para pemeluknya untuk bersikap saling terbuka, seperti: (1) Islam

\footnotetext{
${ }^{19}$ Syamsul Arifin, Studi Agama: Perspektif Sosiologi dan Isu-isu Kontemporer, (Malang: UMM Press, 2009), 5.

${ }^{20}$ Max Weber, The Sociology of Religion, terj. Yudi Santoso, (Yogyakarta: IRCisoD, 2012), 492.
} 
tidak menerima seluruh jenis dan kebudayaan tanpa adanya selektif atau berdasarkan pemilihan terlebih dahulu, dan (2) Islam mendorong manusia agar memiliki ilmu pengetahuan dengan cara menggunakan akalnya untuk berpikir, merenung, dan sebagainya.

Seharusnya tidak perlu mengherankan, bahwa Islam selaku agama besar terakhir, mengklaim sebagai agama yang memuncaki proses pertumbuhan dan perkembangan agama-agama dalam garis tersebut. Tetapi harus diingat, bahwa justru penyelesaian terakhir yang diberikan Islam sebagai agama terakhir untuk persoalan keagamaan itu ialah ajaran pengakuan akan hak agama-agama itu untuk berada dan dilaksanakan. Upaya mencari titik temu antara berbagai kelompok agama, apapun bentuk eksoteriknya (tata cara beribadah, tempat ibadah, ungkapan-ungkapan bahasa agama, dan peradaban yang bersifat simbolik lainnya). Inilah sifat esoterik agama, sekaligus menjadi jantung semua agama (the heart of religions). Kendati demikian, agama memiliki kesatuan dalam berbagai agama-agama dengan bentuk ritualritualnya.

\section{Gambar 1:}

Eksoterisme dan Esoterisme Agama ${ }^{21}$

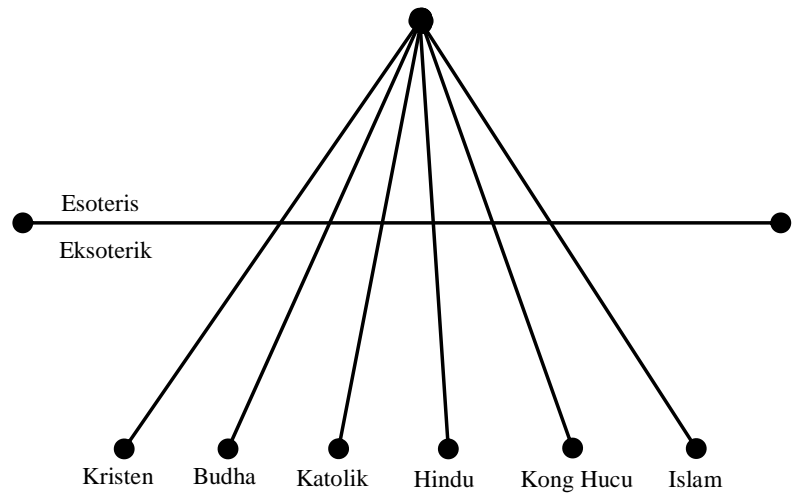

Gambar di atas menunjukkan bahwa dalam ajaran masing-masing agama memiliki metode tersendiri dalam bentuk eksoteriknya, secara substansial "inti penilaian" (core values) adalah kekuasaan Tuhan. Bila berbicara mengenai ritualritual peribadatan manusia berdasarkan ajaran agama-agamanya masih bersifat esoterik. Selama ini agama hanya dipahami secara sempit dan lebih terarah kepada penampilan lahiriah (eksoterik) yang beragam sementara substansi agama (esoterik) secara fundamental tidak dilihat secara mendalam. Akibatnya, terjadi keekslusifan dalam beragama dan memandang agama lain sebagai salah atau sesat. Keadaan

\footnotetext{
${ }^{21}$ Arifin, Studi ..., 97.
} 
demikian tentu akan memunculkan ketakharmonisan. Bertolak dari pengalaman historis dan pandangan teologis yang sempit dan tertutup dalam sekat-sekat eksoterik itu, agaknya kita harus melihat ke depan, dalam suasana global dan plural, sikap mau menang sendiri dan mau menikmati surga sendiri tidak dapat dipertahankan lagi, justru kita harus memiliki wawasan teologi yang luas dan transparan. ${ }^{22}$ Sekarang, apabila kita tidak bisa membuat klaim-klaim otoritatif apa pun mengenai kebenaran esoteris agama secara umum selain mengaitkannya kepada tradisi eksoteris, sejumlah kontradiksi dalam dokrin tidak akan menafikan akan interior netral dari esensi agama. $^{23}$

Pada prinsipnya, agama adalah petunjuk Tuhan yang bertujuan membawa keselamatan dan kedamaian bagi manusia sejagat. Agama mengandung norma-norma dan nilai-nilai yang dapat menampung kepentingan manusia yang berbeda-beda, sehingga tercipta suatu kehidupan yang damai dan tenteram di muka bumi. Ajaran agama merupakan formal untuk menumbuhkan kekisruhan rohani manusia, sehingga dapat memberikan kesejukan dalam kehidupan. Oleh sebab itu, tidak ada satu agama pun yang mengajarkan suatu yang buruk atau membawa keburukan bagi kehidupan insan. Segenap norma dan nilai dalam ajaran-ajaran agama-agama senantiasa mengarahkan manusia kepada kedamaian dan kesejukan rohani. Alat pendukung peningkatan kualitas dan kemampuan menghadapi tantangan-tantangan adalah memahami ajaran Islam. Permasalahan yang timbul ialah bagaimana memberikan pencerahan tentang ajaran Islam, agar agama Islam yang diamalkan itu mampu menggerakkannya untuk mengubah nasib guna memperoleh kesejahteraan hidup didunia dan akherat. Bahkan berusaha memperbaiki nasib adalah satu perintah agama juga. Agama tidak menyuruh umatnya bersikap fatalistik karena segala sesuatu sudah ditentukan oleh Tuhan dalam arti harfiyah, karena itu segala perbuatan hanya bisa datang dari Tuhan semata-mata.

Dalam sejarah kehidupan umat Islam, sikap inklusif terhadap agama telah diletakkan sejak saat-saat awal Nabi Muhammad SAW. membangun Negara Madinah. Setelah Nabi berhijrah ke kota Madinah, beliau segera melihat kenyataan akan adanya pluralitas yang terdapat di kota Madinah. Pluralitas yang dihadapi oleh Nabi antara lain tidak hanya karena perbedaan etnis semata, akan tetapi juga perbedaan yang disebabkan agama. Madinah tidak bersifat homogen dengan agama, di samping penduduk yang beragama Islam, terdapat pula penduduk yang beragama

\footnotetext{
${ }^{22}$ Yunasril Ali, Sufisme dan Pluralisme: Memahami Hakikat Agama dan Relasi Agamaagama, (Jakarta: PT. Eles Media Komputindo, 2012), 90.

${ }^{23}$ M. Legenhausen, Pluralitas dan Pluralisme Agama: Keniscayaan Pluralisme Agama sebagai Fakta Sejarah dan Kerancuan Konsep Pluralisme Agama, (Jakarta: Shadra Press, 2010), 172.
} 
Yahudi dan Nasrani bahkan juga kaum musyrikin. Melihat pluralitas keagamaan ini Nabi Muhammad SAW. berinisiatif membangun kebersamaan dengan yang berbeda agama, kemudian melahirkan apa yang dikenal dengan Piagam Madinah. Piagam Madinah merupakan dokumen politik resmi pertama yang meletakkan prinsip kebebasan beragama. ${ }^{24}$ Pada pasal ini memberikan jaminan kebebasan beragama, di antara wujud kebebasan beragama ini adalah menjalankan ibadat sesuai dengan ajaran agama masing-masing. Kebebasan beragama di Madinah pada masa Nabi Muhammad SAW. dapat dibuktikan juga dengan adanya pertemuan tiga agama di Madinah, yaitu agama Islam, Yahudi, dan Nasrani. Dalam pertemuan ini, di antara mereka merupakan para tokoh-tokoh yang ahli di bidang agama, kemudian mereka mendialogkan masalah teologis antar-tokoh agama dari tiga agama tersebut. Pertemuan tiga agama tersebut tidak membawa kesatuan dalam beragama. Kaum Yahudi dan Nasrani tetap pada pendiriannya, tetapi Nabi Muhammad SAW. tidak memaksa mereka untuk mengubah agama mereka.

\section{Penutup}

Dari beberapa mengenai karakteristik ajaran Islam yang secara dominan ditandai oleh pendekatan normatif, historis, dan filosofis tersebut dilihat bahwa ajaran Islam memiliki ciri-ciri yang secara keseluruhan amat ideal. Islam juga telah tampil sebagai sebuah disiplin ilmu keislaman dengan pelbagai cabangnya. Karakteristik ajaran Islam memuat berbagai bidang, seperti bidang agama, mu'amalah (kemanusiaan) yang di dalamnya termasuk masalah pendidikan, ilmu pengetahuan, kebudayaan, sosial, ekonomi, politik, kehidupan, lingkungan hidup, kesehatan, pekerjaan, serta Islam sebagai sebuah disiplin ilmu. Untuk itu, umat Islam harus mampu mengakomodir hal penting yang bernilai kemanusiaan dalam beberapa bidang pengetahuannya yang berlandaskan pada ajaran Islam. Dalam hubungan sosial "hablul minnas" yang berada dalam bingkai "kesatuan dan keragaman" umat beragama, Islam mengajurkan untuk mampu hidup bersanding dalam kehidupannya dengan menunjukkan sikap solidaritas dan cinta-damai yang tinggi di dalam lingkungan sosial, masyarakat dan bangsa. Karena itu Islam agama yang mengajarkan perdamaian, toleransi, terbuka, kebersamaan, egaliter, kerja keras yang bermutu, demokratis, adil, seimbang antara hubungan dunia dan akherat, berharta, memiliki kepekaan terhadap masala-masalah sosial kemasyarakatan. Mengutamakan pencegahan dari pada penyembuhan dalam bidang kesehatan dengan cara

${ }^{24}$ Nurcholish Madjid, Islam Doktrin dan Peradaban: Sebuah Tela'ah Kritis tentang Masalah Keimanan, Kemanusian, dan Kemodernan, (Jakarta: Yayasan Wakaf Paramadina, 1992), 195. 
memperhatikan segi kebersihan badan, pakaian, makanan, tempat tinggal, lingkungan, dan sebagainya.

\section{DAFTAR PUSTAKA}

Munawwir, A. W. Kamus Bahasa Arab-Indonesia Terlengkap. Surabaya: Penerbit Pustaka Progressif, 1984.

at-Tariqi, Abdullah Abdul Husain. Ekonomi Islam: Prinsip, Dasar, dan Tujuan, terj. M. Irfan Syofwani. Yogyakarta: Magistra Insania Press, 2004.

Nata, Abudin. Metodologi Studi Islam. Jakarta: RajaGrafindo Persada, 2011.

Sudrajat, Ajat dkk. Pendidikan Agama Islam. Yogyakarta: UNY Press, 2008.

S. Turner, Bryan. Religion and Social Theory, terj. Inyiak Ridwan Munir. Yogyakarta: IRCiSoD, 2012.

Legenhausen, M. Pluralitas dan Pluralisme Agama: Keniscayaan Pluralisme Agama sebagai Fakta Sejarah dan Kerancuan Konsep Pluralisme Agama. Jakarta: Shadra Press, 2010.

Weber, Max. The Sociology of Religion, terj. Yudi Santoso. Yogyakarta: IRCisoD, 2012.

Asy'arie, Musa. Dialektika Agama untuk Pembebasan Spiritual. Yogkarta: LESFI, 2002.

Madjid, Nurcholish. Islam Doktrin dan Peradaban: Sebuah Telaah Kritis tentang Masalah Keimanan, Kemanusian, dan Kemodernan. Jakarta: Yayasan Wakaf Paramadina, 1992.

Susanto, Susanto. Pemikiran Pendidikan Islam. Jakarta: Amzah, 2010.

Arifin, Syamsul. Studi Agama: Perspektif Sosiologi dan Isu-isu Kontemporer. Malang: UMM Press, 2009.

Bakri, Syamsul. Peta Sejarah Peradaban Islam. Yogyakarta: Fajar Media Press, 2011.

Ali, Yunasril. Sufisme dan Pluralisme: Memahami Hakikat Agama dan Relasi Agama-agama. Jakarta: Eles Media Komputindo,2012. 